\title{
Childhood Brain Stem Glioma
}

National Cancer Institute

\section{Source}

National Cancer Institute. Childhood Brain Stem Glioma. NCI Thesaurus. Code C9042.

A glioma that arises from the brain stem and occurs during childhood. 